Primljen / Received: 13.6.2014. Ispravljen / Corrected: 22.1.2015.

Prihvaćen / Accepted: 5.2.2015.

Dostupno online / Available online: 10.3.2015.

\section{Determination of dynamic parameters of double-layered brick arches}

Author:

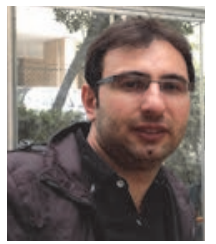

Assist.Prof. Ferit Cakir, PhD. CE

Amasya University

Faculty of Architecture

Department of Architecture

ferit.cakir@amasya.edu.tr
Original scientific paper

\section{Ferit Cakir}

\section{Determination of dynamic parameters of double-layered brick arches}

Masonry arches assume a very important role in construction industry, and we find them in many historical structures all over the world. Dynamic parameters, frequency, and damping of masonry arches are defined in this paper using the Experimental Modal Analysis (EMA). Double-layered arches were built using standard hollow bricks and traditional Horasan mortar. The brick arches were tested with an impact hammer, and the arch response was measured using a laser vibrometer. Experimental tests were compared with numerical modelling in order to verify adequacy of physical models.

Key words:

masonry structures, double-layered brick arches, experimental modal analysis, finite-element method

Izvorni znanstveni rad

\section{Ferit Cakir}

\section{Određivanje dinamičkih parametara dvoslojnih lukova od opeke}

Zidani lukovi imaju važnu ulogu u građevinarstvu, a nalazimo ih u mnogim povijesnim građevinama diljem svijeta. U ovom su radu dinamički parametri, frekvencija i prigušenje zidanih lukova određeni eksperimentalnom modalnom analizom (EMA). Dvoslojni lukovi zidani su standardnom šupljom opekom i tradicionalnim Horasan mortom. Ispitivanje dvoslojnih lukovi provedeno je s udarnim čekićem, a odzivi lukova zabilježeni su laserskim vibrometrom. Za potrebe verifikacije izrađenih prostornih modela provedena je usporedba eksperimentalnih ispitivanja s numeričkim proračunima.

Ključne riječi:

zidane konstrukcije, dvoslojni lukovi od opeke, eksperimentalna modalna analiza, metoda konačnih elemenata

Wissenschaftlicher Originalbeitrag

Ferit Cakir

\section{Ermittlung dynamischer Parameter doppelter Mauerwerksbögen}

Mauerwerksbögen nehmen im Bauwesen eine wichtige Rolle ein und treten weltweit häufig in historischen Bauwerken auf. In dieser Arbeit werden dynamische Parameter, Frequenz und Dämpfung von Mauerwerksbögen durch experimentelle Modalanalysen (EMA) ermittelt. Die doppelten Mauerwerksbögen sind aus herkömmlichem Hohlziegelstein und traditionellem Horasan Mörtel zusammengesetzt. Die Bogenstrukturen sind mit dem Schlaghammer untersucht und das entsprechende Verhalten ist mittels eines Laser-Vibrometers erfasst worden. ZurVerifikation erstellter räumlicher Modelle ist ein Vergleich experimenteller Versuche und numerischer Berechnungen durchgeführt worden.

Schlüsselwörter:

Mauerwerk, zweifache Mauerwerksbögen, experimentelle Modalanalyse, Finite-Elemente-Methode 


\section{Introduction}

Structures are nowadays generally made of modern construction materials such as reinforced concrete or steel. However, most ancient structures are made of masonry materials such as stone or brick. Masonry structures generally maintain their initial performance, which points to the complexity of their structural behaviour. Understanding structural behaviour of masonry structures is a very complex and obscure issue. An appropriate information about structural components of masonry structures is required to understand their structural behaviour. Although masonry structures have many different structural components, their vital elements are arches, domes, walls, and foundations.

Masonry structures are exposed to many different external and internal effects throughout their useful lives. Although these structures are very durable, some historical structures have unfortunately deteriorated, suffered damage, collapsed, or failed due to various effects. Recent studies show that masonry structures are vulnerable to earthquakes. Seismic effects have been among the most important reasons for the collapse of masonry structures [1-5]. Hence, many historical structures are at risk with regard to seismic events, and their capability to resist seismic loads is poor. Although scientists have studied masonry structures and their structural behaviour, the dynamic behaviour of their structural components has rarely been investigated [6-8]. The prediction of the response of structures to dynamic effects such as earthquakes is very important in terms of seismic safety. Therefore, dynamic parameters such as frequency, mode shape, and damping ratio, must be determined. In this study, modal parameters of all arches were determined through experimental modal analysis (EMA). EMA, also known as the frequency response function test, is one of the most important experimental tests. It is based on the measurement of vibration response following the impact applied onto the structure. Therefore, dynamic parameters such as frequency, mode shape, and damping ratio of the double-layered masonry arch, were determined in this study using the EMA procedure.

\section{Materials and methods}

\subsection{Traditional Horasan mortar}

Traditional Horasan mortar used to be a preferred brick bonding material and was therefore used in many historical structures. Horasan mortar, also known as the "Horasan concrete", is the traditional mixture that was used in buildings originating from Byzantine, Seljuk, and Ottoman periods. This mortar is generally made of binding lime, fine sand, and brick powder, and it is as strong as stone and concrete [9]. Horasan mortar had been widely used in Ottoman structures in Anatolia. In addition, this mortar is the basis for the present-day concrete. Hydraulic lime is currently used as binding material in Horasan mortar because of its cement-free feature, high deformation capacity, and porosity. Therefore, hydraulic lime based mortar is used as Horasan mortar in this study. Stone powder, fine sand, lime paste, brick powder, and Albaria Calce Albazzana ${ }^{\circledR}$ bonding material (supplied by BASF Chemical Company) were mixed in equal proportion by weight (Figure 1) to obtain the mortar. Albaria is a cement-free natural hydraulic lime that is burnt at $900{ }^{\circ} \mathrm{C}$ in traditional oven, [10].

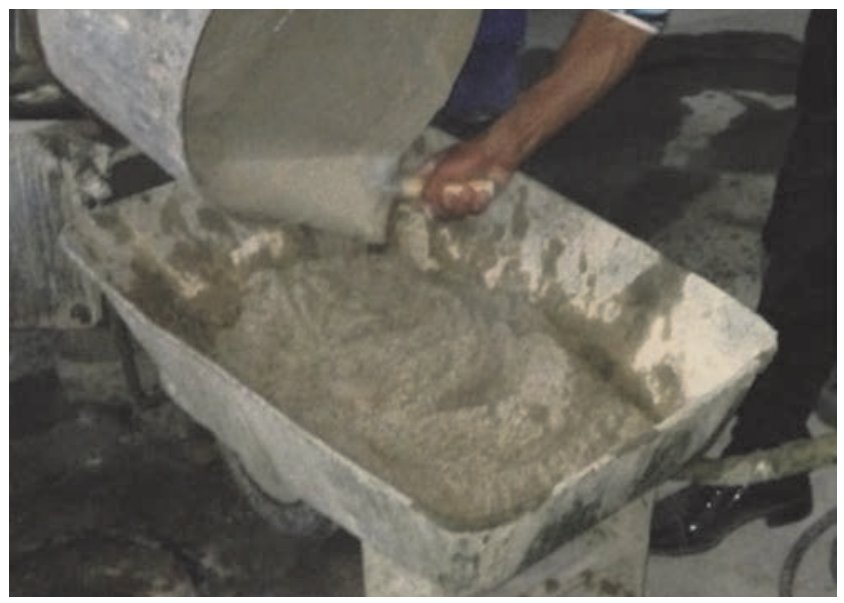

Figure 1. Preparation of traditional Horasan mortar

\subsection{Masonry hollow bricks}

Standard hollow bricks, $90 \mathrm{~mm} \times 190 \mathrm{~mm} \times 50 \mathrm{~mm}$, were used in this study. In the first step, newly manufactured bricks were cleaned with water in order to remove any contamination and dust from the brick surfaces, and to enable an effective adherence between the brick and mortar. After surface cleaning, masonry bricks were dried at room temperature for two days (Figure 2).

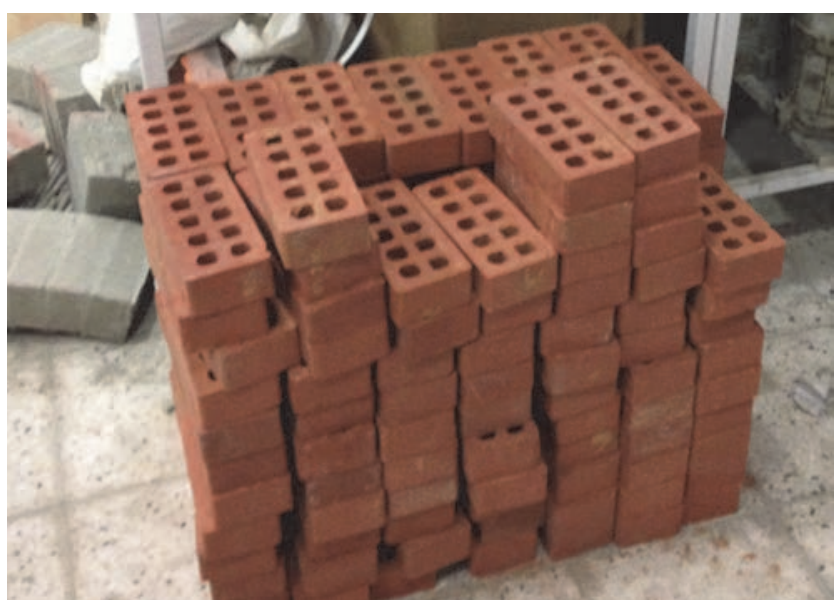

Figure 2. Standard hollow bricks

\subsection{Masonry brick arches}

Double-layered semi-circular arches $1000 \mathrm{~mm}$ in internal span, $500 \mathrm{~mm}$ in rise, and $180 \mathrm{~mm}$ in thickness, were prepared in the scope of this study (Figure 3). The arches were built on timber shutters, and were removed two days after arch construction. Subsequently, all arches were allowed to cure for ten weeks (Figure 3). 

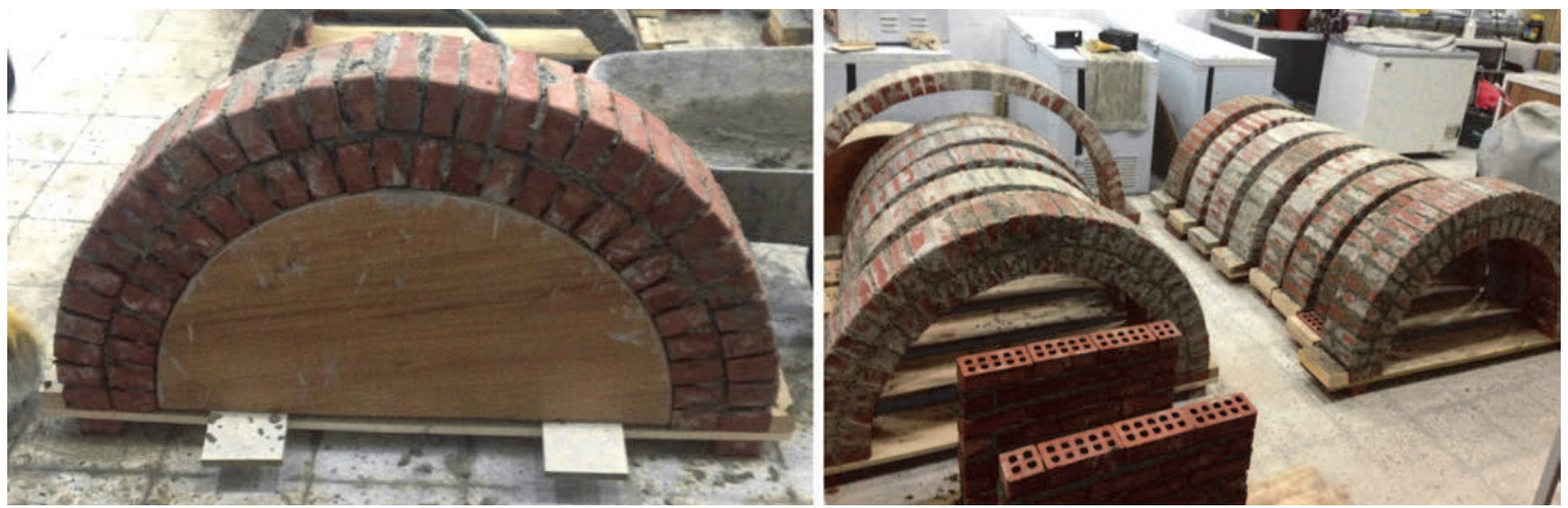

Figure 3. Stacking of masonry arches for curing

\section{Mechanical characteristics of materials}

The most important mechanical properties of masonry units are compressive strength and tensile strength. Therefore, compressive and tensile tests were conducted in this study to determine mechanical parameters of construction materials. Mechanical parameters for masonry materials were obtained from test samples (Figure 4). Compressive strength values were determined from compression tests conducted on five cubes (50 $\mathrm{mm} \times 50 \mathrm{~mm} \times 50 \mathrm{~mm}$ ) according to TS 699, Turkish Building Code [11] (Table 1). In addition, tensile strength values were obtained from three-point bending tests conducted on five prisms $(50 \mathrm{~mm}$ $\times 100 \mathrm{~mm} \times 200 \mathrm{~mm}$ ) according to Turkish Building Codes, TS EN 1467 and 1469 (Table 1) [12, 13]. Mortar strength was defined by the compression and three-point bending tests of mortar samples at 28 days. Mechanical properties of materials were obtained by testing samples at laboratories of the Department of Civil Engineering at Ataturk University, Erzurum, Turkey.

Table 1. Compressive strengths of the bricks and mortars

\begin{tabular}{|c|c|c|c|c|}
\hline \multirow{2}{*}{$\begin{array}{c}\text { Sam- } \\
\text { ples }\end{array}$} & $\begin{array}{c}\text { Compressive } \\
\text { strength } \\
{\left[\mathrm{N} / \mathrm{mm}^{2}\right]}\end{array}$ & $\begin{array}{c}\text { Tensile } \\
\text { strength } \\
{\left[\mathrm{N} / \mathrm{mm}^{2}\right]}\end{array}$ & $\begin{array}{c}\text { Compressive } \\
\text { strength } \\
{\left[\mathrm{N} / \mathrm{mm}^{2}\right]}\end{array}$ & $\begin{array}{c}\text { Tensile } \\
\text { strength } \\
{\left[\mathrm{N} / \mathrm{mm}^{2}\right]}\end{array}$ \\
\hline 1 & 16.28 & 2.08 & 10.08 & 1.48 \\
\hline 2 & 16.35 & 2.15 & 10.10 & 1.52 \\
\hline 3 & 16.92 & 2.02 & 9.89 & 1.41 \\
\hline 4 & 16.24 & 2.14 & 10.05 & 1.55 \\
\hline 5 & 16.84 & 2.10 & 9.96 & 1.46 \\
\hline
\end{tabular}
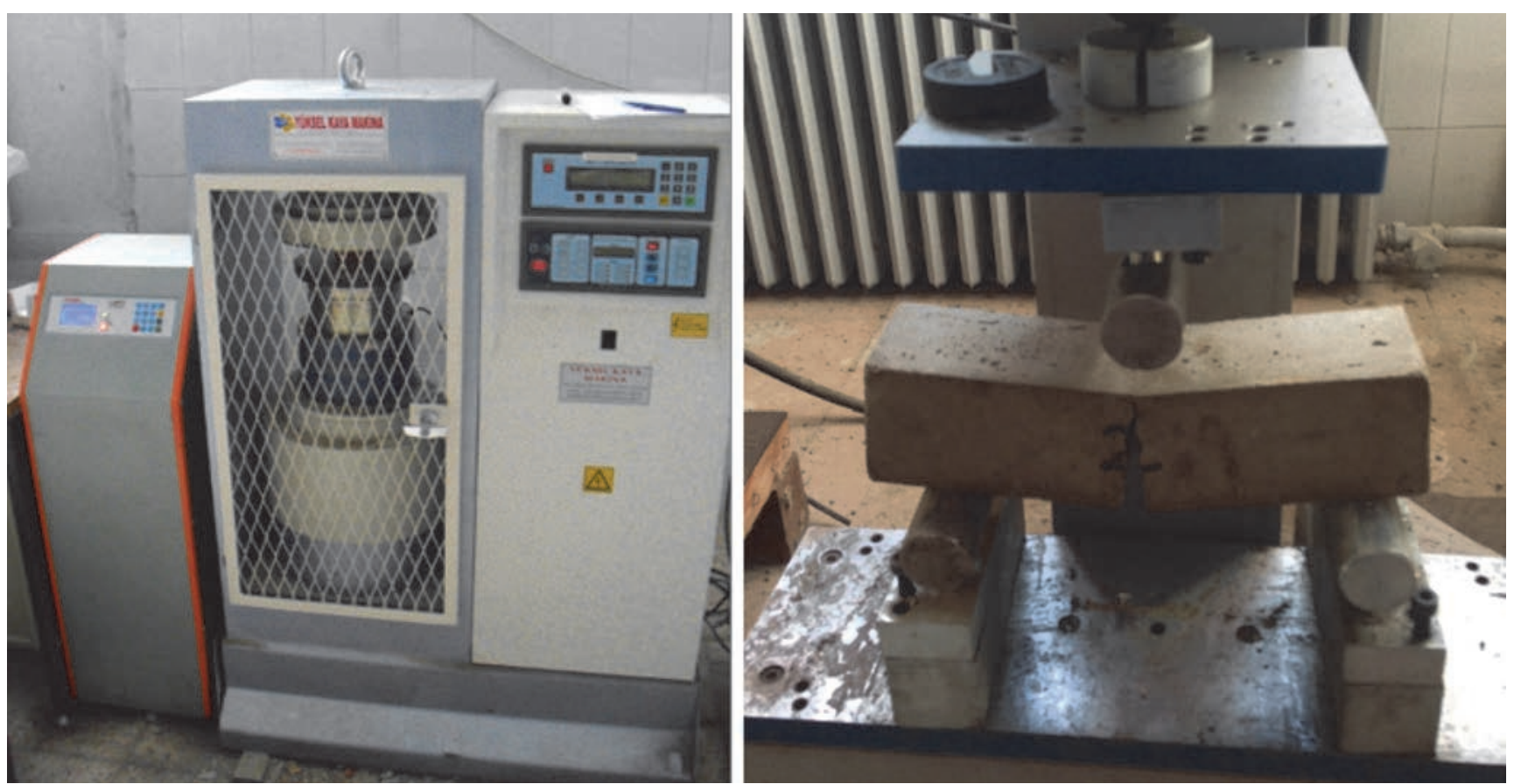

Figure 4. Compressive and three-point bending tests 


\section{Experimental Modal Analysis (EMA)}

Modal parameters, such as natural frequency and mode shapes, have always been important in the analysis of dynamic behaviour of structures. EMA, also known as frequency response function testing, is a preferred method for dynamic identification of structures in general $[14,15]$. EMA uses the principle of response measurement in relation to the load applied onto the structural system. Modal parameters of the structural system are determined through structural response to the load applied. Hence, EMA is frequently preferred for determination of modal parameters [14, 15]. Therefore, EMA is applied in this study to assess dynamic parameters. In the first step, all devices in the laboratory were closed, and people were prevented from entering

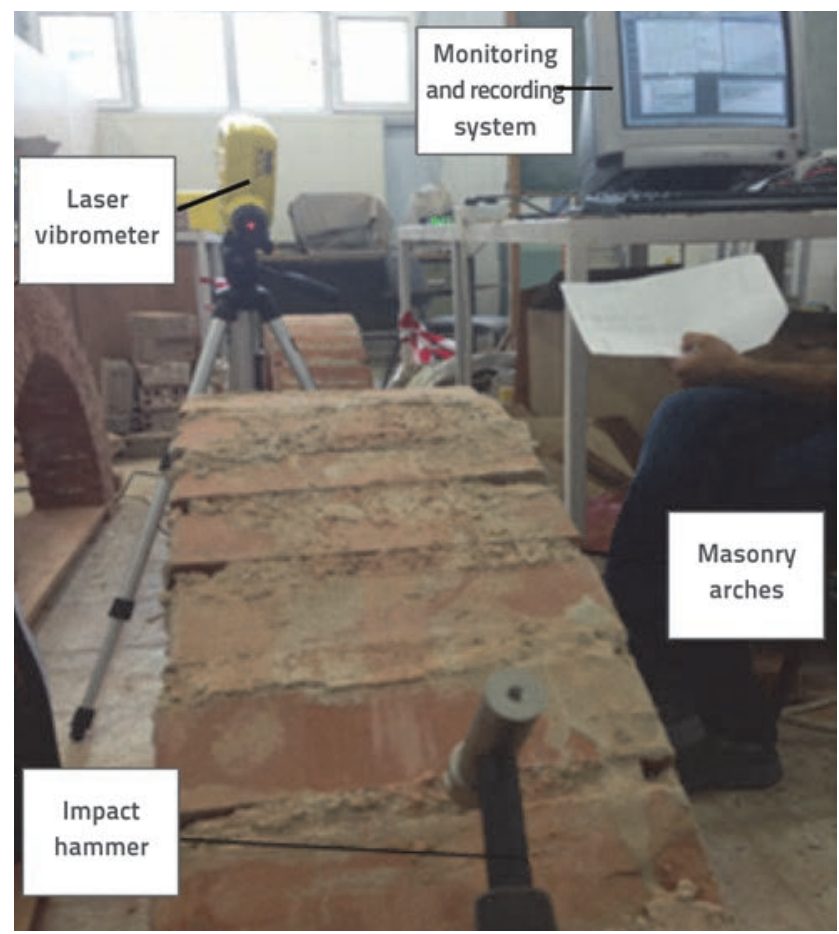

Figure 5. Experimental test set-up

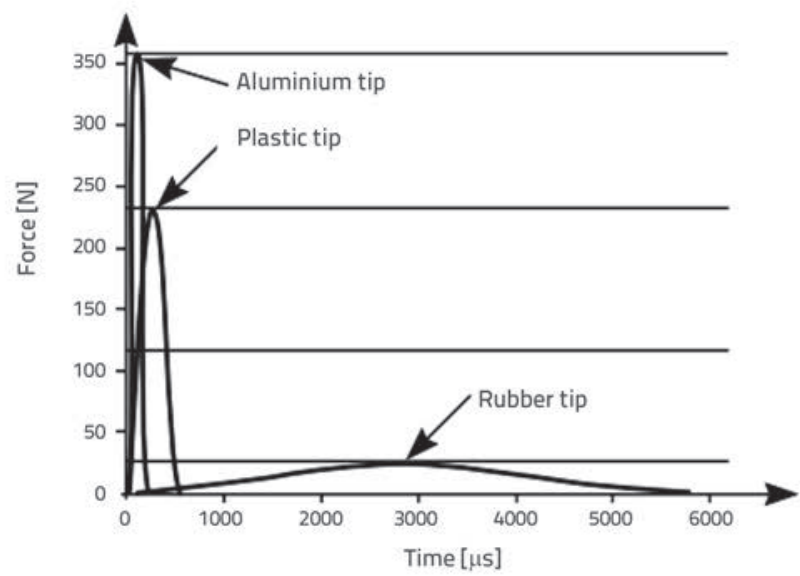

the laboratory in order to isolate unwanted ambient vibrations. All masonry arches were primarily fixed to the floor, and arches were vibrated with an impact hammer (Brüel \& Kjaer 8206-002). The response of arches to these impacts was measured using a Laser Vibrometer (Ometron $\mathrm{VH} 300+$ ). During the test, all data were recorded with a multi-channel data logger (Brüel \& Kjaer 3050-B-040) (Figure 5)

Following the experimental set-up, the frequencies and damping ratios of the arches were determined using the experimental modal analysis. For this purpose, the arches were vibrated at least five times at the same point, and the linear averaging was applied. The impact hammer causing vibration of arches was weighted at a certain point between two impact forces for stabilization. After each impact force, the monitoring system was used, and all response functions were visually controlled on the screen in order to better understand the vibration. Thanks to these visual observations, only the structural response to impact hammer was recorded. Outside vibrations and noises were discarded in this manner. In all tests, four different impact points were chosen at the quarter span and middle span of the arches in and out of plane (Figure 6). Moreover, the frequency range of this study was $0-500 \mathrm{~Hz}$. For this frequency range, a rubber impact tip was preferred (Figure 7).

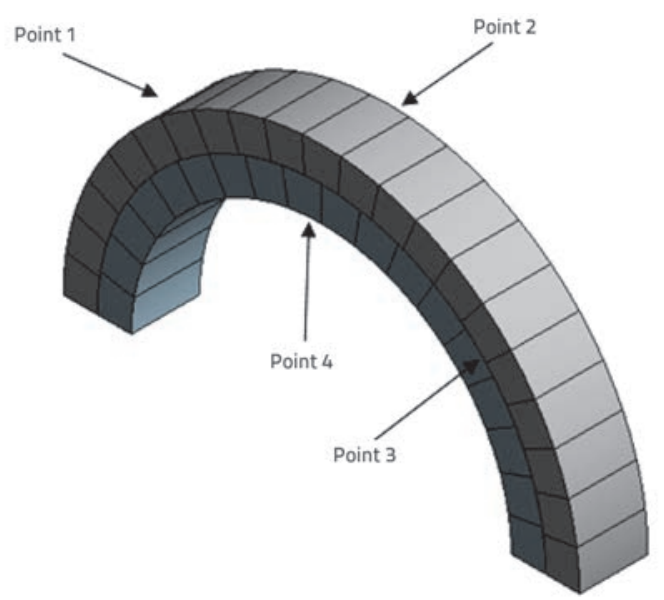

Figure 6. Impact points on the arch

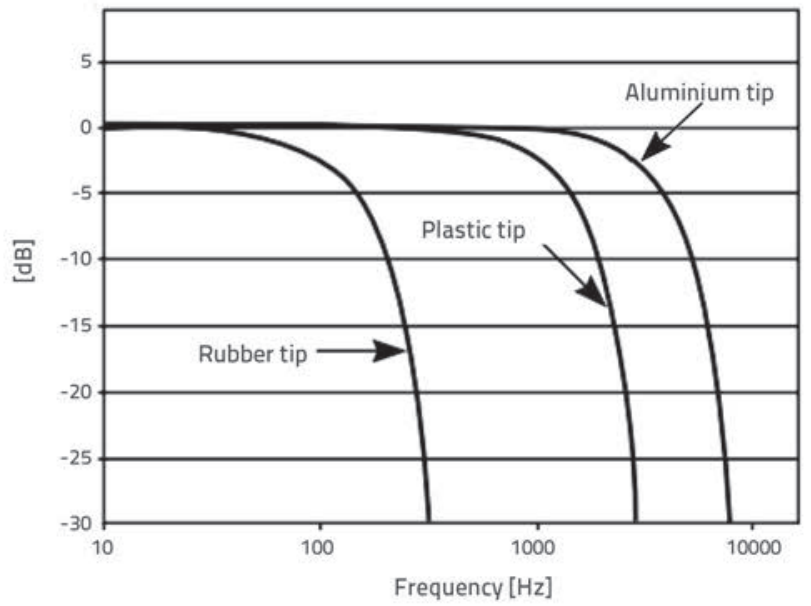

Figure 7. Impulse shapes for the hammer tips (a) force range, (b) frequency range of hammer tips [16] 

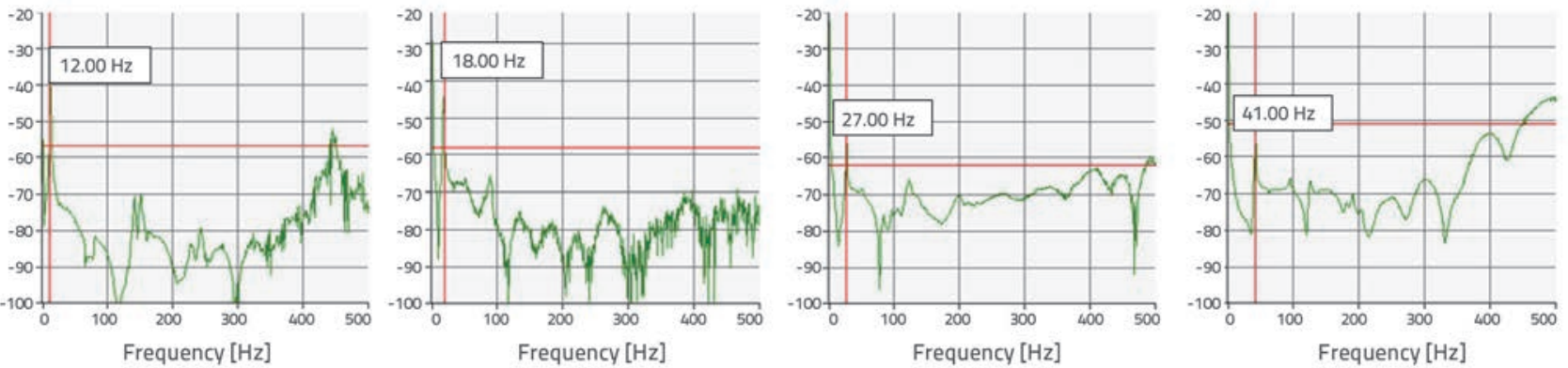

Figure 8. Some frequency values obtained from different impact points
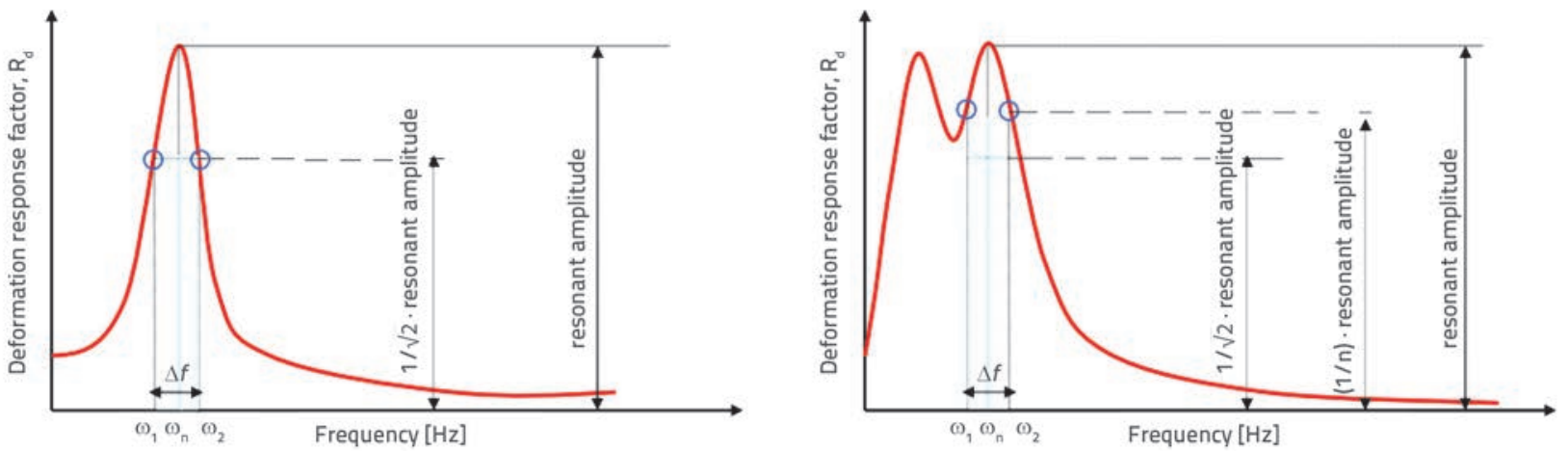

Figure 9. Half-power bandwidth technique [17]

Natural frequencies were identified from the peaks of the frequency response functions (FRF). The FRF provides the input and output relations between the impact point and the measurement point on the arch as a function of frequency. The selected peaks in the frequency response function were used to define the modes. Dynamic parameters such as natural frequencies, damping ratios and mode shapes were obtained from a set of FRF curves. In this study, the Peak Picking method was preferred to determine the frequencies. In this method, the narrow peaks in the curve describe high resonances. Figure 8 presents the frequency response function obtained from different impact points, while Table 2 summarizes the frequencies and periods of the structure.

Table 2. Frequencies and periods obtained from EMA

\begin{tabular}{|c|c|c|c|}
\hline Mode & Impact point & $\begin{array}{c}\text { Frequency } \\
{[\mathrm{Hz}]}\end{array}$ & $\begin{array}{c}\text { Period } \\
{[\mathrm{S}]}\end{array}$ \\
\hline 1 & Point 2 & 4.25 & 0.24 \\
\hline 2 & Point 1 & 11.35 & 0.09 \\
\hline 3 & Point 3 & 15.10 & 0.07 \\
\hline 4 & Point 4 & 18.85 & 0.05 \\
\hline 5 & Points 1 - 3 & 26.35 & 0.04 \\
\hline 6 & Points 2 - 4 & 32.12 & 0.03 \\
\hline
\end{tabular}

In addition, damping ratios were also determined using FRF graphs. The damping ratios were calculated by the method called half-power bandwidth [15]. Figure 9 demonstrates the half-power bandwidth technique. $\omega_{1}$ and $\omega_{2}$ are the half-power points of the bandwidth and $\omega_{n}$ is the frequency value. The modal damping ratio is calculated with the formula shown below, and Figure 10 shows the damping ratio screen view. The first six frequencies, periods, and damping ratios for the double-layered arch are presented in Table 3.

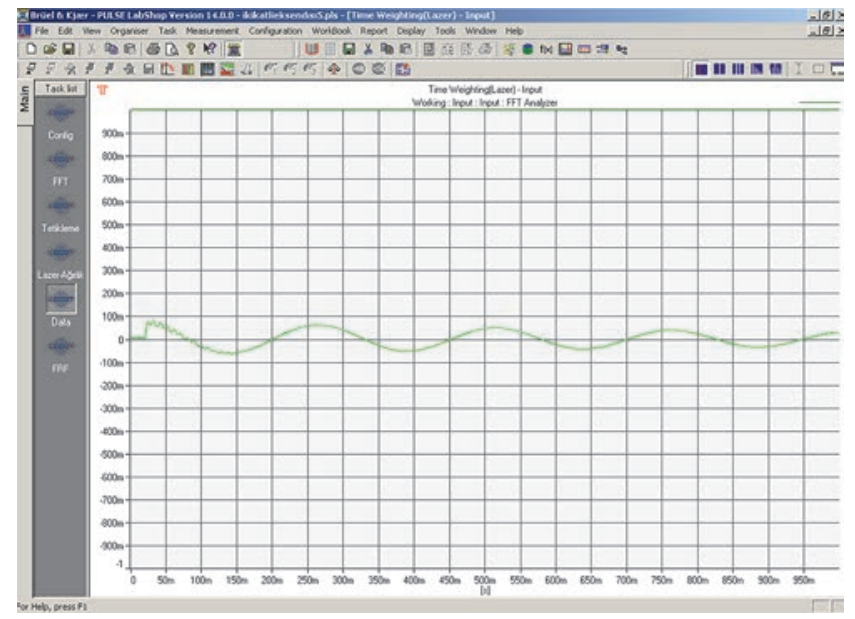

Figure 10. The damping ratio screen view 
Table 3.Damping ratios obtained from EMA

\begin{tabular}{|c|c|c|}
\hline Mode & Impact point & $\begin{array}{c}\text { Damping ratio } \\
{[\%]}\end{array}$ \\
\hline 1 & Point 2 & 5.36 \\
\hline 2 & Point 1 & 3.92 \\
\hline 3 & Point 3 & 3.09 \\
\hline 4 & Point 4 & 2.63 \\
\hline 5 & Points 1 - 3 & 2.52 \\
\hline 6 & Points 2 - 4 & 2.15 \\
\hline
\end{tabular}

\section{Numerical analysis}

Advances in computer technology have facilitated numerical analysis and examination of structural behaviour via threedimensional models. Thus, the determination of static and dynamic behaviour of masonry structures with the finite element method has recently become one of the most common methods. A three-dimensional finite element model was developed in this study based on the structural state and geometrical constraints of the arch. The three-dimensional finite element model was analysed for the double-layered arch investigated in the scope of this study. In this respect, the FEA program called ANSYS Workbench was used to analyse the arch with SOLID186 elements, which has 20 nodes and three degrees of freedom per node. In the first model, the double-layered arch was discretized with 7560 solids, corresponding to 37960 nodes (Figure 11). According to the Turkish Earthquake Code (TEC 2007) [18], the modulus of elasticity (E) for masonry units used in masonry construction can be calculated using the formula; $E=200 . f$, where $f$ is an average compressive strength of masonry unit in MPa. Masonry arches were made of bricks and mortar. According to [17], the modulus of elasticity for the new composite material (brick + mortar) could be obtained based on homogenization procedures as follows:

$$
E=\frac{t_{m}+t_{u}}{\frac{t_{m}}{E_{m}}+\frac{t_{u}}{E_{u}}} \rho
$$

where $t_{m}$ represents the mortar thickness, $t_{u}$ represents the brick height, and $\rho$ represents the efficiency factor with respect to the deficient bond between mortar and brick. Finally, $E_{m}$ and $E_{u}$ represent the modulus of elasticity of mortar and brick, respectively. The thickness of brick used in this study is $50 \mathrm{~mm}$, while the mortar is almost $10 \mathrm{~mm}$ in average thickness. The calculated moduli of elasticity for bricks and mortars amount to 3395.2 MPa and 2003.2 $\mathrm{MPa}$, respectively. Moreover, the efficiency factor of 0.5 is adopted for masonry structures [17]. When all values used in formula (1) are taken into account, the calculated elasticity modulus of the new composite material (brick + mortar) amounts to $1521.36 \mathrm{MPa}$.

Hence, the moduli of elasticity were calculated using the above formula in all three-dimensional finite element models. The Poisson ratio of 0.2 from was taken from similar studies [15], and the mass per unit volume was accepted as an average value of experimental tests.

To get the most appropriate results in the numerical analyses, a single layered reference masonry arch, with previously determined boundary conditions, was taken into consideration in the first step, and the frequency values obtained at the reference masonry arch were compared with frequency values obtained through numeric analyses. Based on these comparisons, it was determined that experimental data differ from analytical data. To eliminate these differences, a calibration study was conducted using the numerical model recommended in literature $[15,19$, $20,21]$. The comparisons allowed some modifications of material properties so as to obtain an optimum level, without changing boundary conditions. This amendment also enabled consistency between numerical analyses and experimental studies.

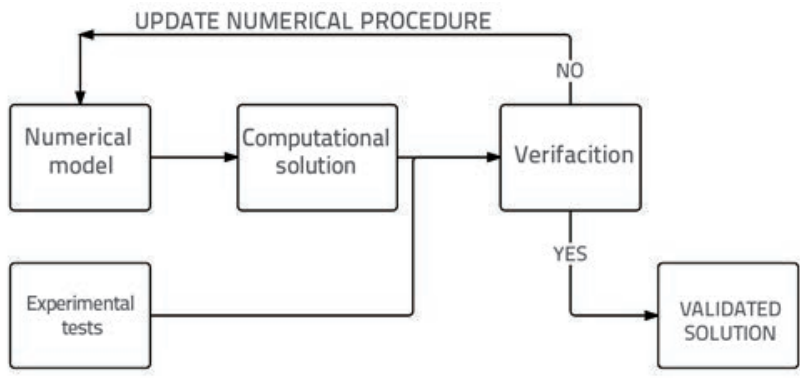

Figure 12. FEM updating process
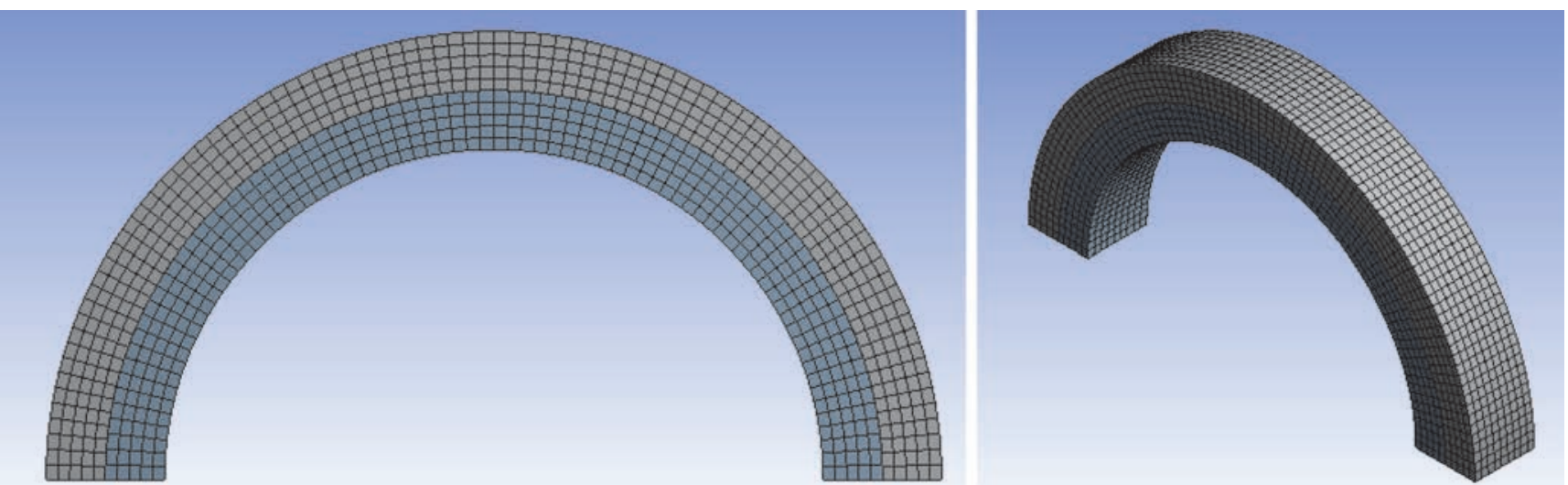

Figure 11. Finite element model of double-layered masonry arch 

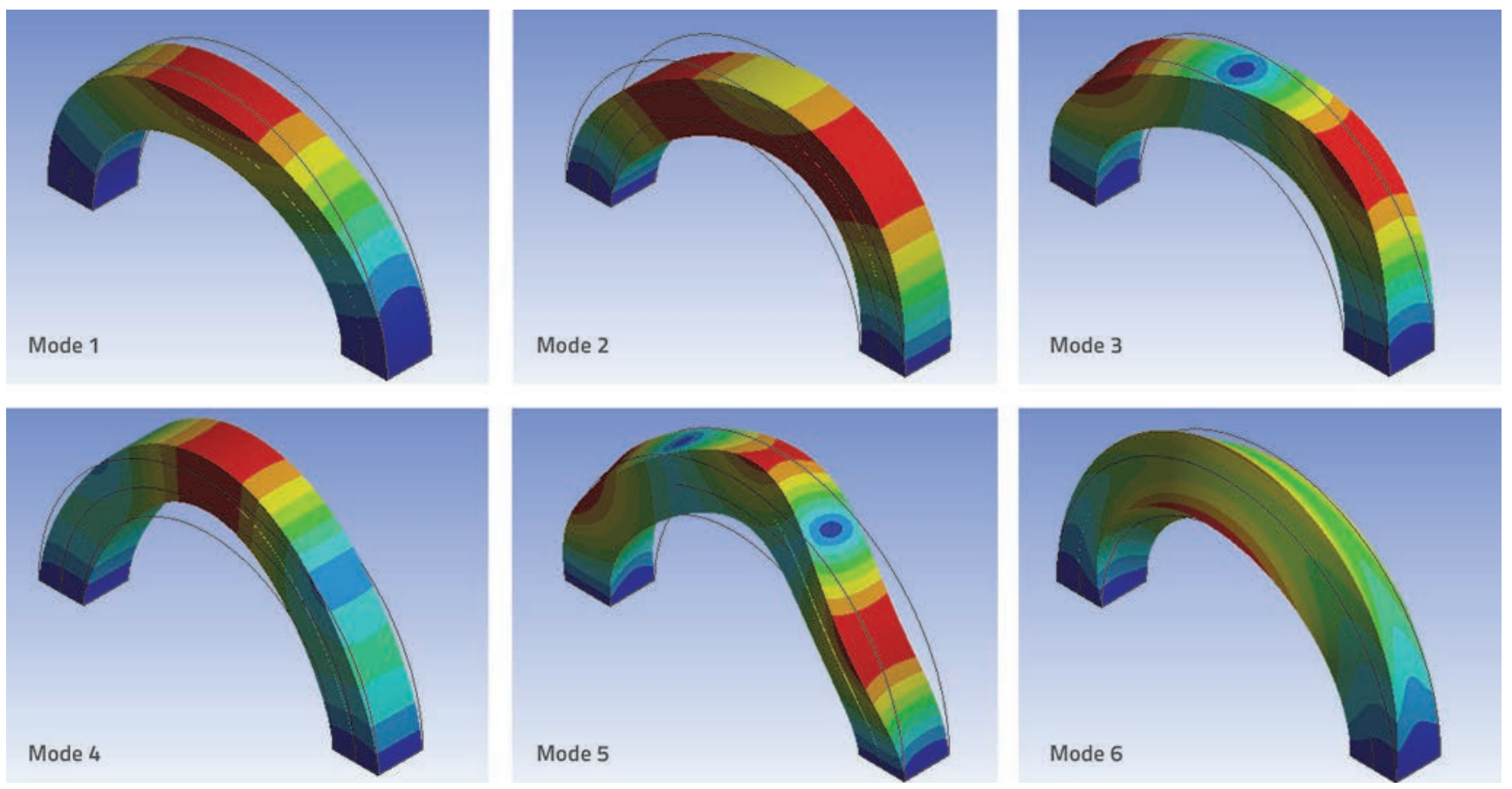

Figure 13. Mode shapes and directions

Table 4. Frequencies, periods and ratio of effective mass to total mass obtained from FEA

\begin{tabular}{|c|c|c|c|c|c|}
\hline \multirow{2}{*}{ Mode } & Frequency & Period & \multicolumn{2}{|c|}{ Ratio of efective mass to total mass } \\
\cline { 3 - 6 } & {$[\mathrm{Hz}]$} & $\mathbf{X}$ & \multicolumn{1}{|c|}{$\mathbf{Y}$} & $\mathbf{Z}$ \\
\hline 1 & 4.13 & 0.24 & 0.66074 & $1.14 \cdot 10^{-23}$ & $5.91 \cdot 10^{-26}$ \\
\hline 2 & 11.30 & 0.09 & $2.42 \cdot 10^{-24}$ & 0.73748 & $3.49 \cdot 10^{-20}$ \\
\hline 3 & 14.55 & 0.07 & $4.30 \cdot 10^{-21}$ & $0.16 \cdot 10^{-21}$ & $1.39 \cdot 10^{-23}$ \\
\hline 4 & 18.94 & 0.05 & $2.38 \cdot 10^{-23}$ & $0.26 \cdot 10^{-19}$ & 0.40872 \\
\hline 5 & 26.23 & 0.04 & 0.16504 & $2.19 \cdot 10^{-22}$ & $1.24 \cdot 10^{-22}$ \\
\hline 6 & 31.69 & 0.03 & $9.99 \cdot 10^{-03}$ & $5.04 \cdot 10^{-21}$ & $5.73 \cdot 10^{-22}$ \\
\hline
\end{tabular}

Technically, numerical models are formed by using the finite element method. Numerical model errors mainly result from assumptions such as: material properties and geometrical constraints. Boundary conditions of the structure defined in the model may not be in accordance with the physical system [22]. In this study, mechanical properties of materials were modified as shown in the flowchart given in Figure 12. The numerical analysis was repeated for updated conditions to validate the FEM analysis and the solution.

In this study, the elasticity modulus obtained on the numerical model was changed by about $1.5 \%$, and it amounted to 1500 $\mathrm{MPa}$ instead of $1521.36 \mathrm{MPa}$. The Poisson ratio was 0.20 , and the unit weight was $2800 \mathrm{~kg} / \mathrm{m}^{3}$. Frequency values and mode shapes are presented in Table 4 and Figure 13, respectively.

According to finite element results the first, the second and the fourth modes exhibit a purely bending behavior, whereas the third mode is a torsional one. The fifth and sixth modes are a combination of bending and torsion behaviors.

\section{Conclusion}

The determination of modal parameters, such as natural frequency and mode shapes, has always been an important issue in the design of structures in terms of dynamic loading conditions. In this study, the "Experimental Modal Analysis (EMA)" method was applied in order to determine dynamic characteristics of double-layered arches. For this purpose, the dynamic behaviour of the arches was investigated through experimental tests. Only the first six modes were evaluated in this study, and all experimental studies were supported with the finite element model. Moreover, the experimental and numerical studies were merged together, and the consistency between the data was observed. According to the data presented in Table 2 and Table 3, it can be seen that the first period is around $0.25 \mathrm{~s}$, and that the period is below 0.1 in the second mode. This result proves that the double-layered arches investigated in this paper exhibit a more rigid behaviour than the other type of structures. Finally, it is expected that the analyses and results of this study 
will encourage similar studies focusing on different structural systems and different construction materials.

\section{Acknowledgements}

The authors gratefully acknowledge the support given to this research in the scope of Scientific Research Projects of Ataturk University, Turkey, through the Research Grant 2012/432. The Authors also extend their thanks to Professor Mustafa Yaman, Associate Professor Habib Uysal, and Associate Professor Gürkan Sakar, for their guidance and scientific contributions.

\section{REFERENCES}

[1] Uysal, H., Cakir, F.: Static and dynamic analyses of the historical Erzurum Watchtower, TAC Foundation, Foundation for the Preservation of Turkish Monuments an Environmental, (2013) 1, pp. $72-80$

[2] Bayraktar, A., Coșkun, N., Yalcin, A.: Damages of masonry buildings during the July 2, 2004 Doğubayazıt (Ağrı) earthquake in Turkey, Engineering Failure Analysis, 14 (2007) 1, pp. 147-157.

[3] Kiyono, J., Kalantari, A.: Collapse Mechanism of Adobe and Masonry Structures During the 2003 Iran Bam Earthquake, Bull. Earthq. Res. Inst. Univ. Tokyo, 79 (2004), pp. 157-161.

[4] Lourenco, P.: Computations on historic masonry structures, Structural Engineering and Materials, 4 (2002) 3, pp. 301-319.

[5] Aras, F., Krstevska, L., Altay, G., Taskov, L.: Experimental and Numerical Modal Analyses of a Historical Masonry Palace, Construction and Building Materials, 25 (2011) 1, pp. 81-91.

[6] Camlibel, N.: The analytically investigate of Architect Sinan's Structures, Associate Professorship Thesis, Graduate School of Natural And Applied Sciences, Istanbul Technical University, 1998 Turkey.

[7] Cakir, F.: Assessment of Structural Integrity And Seismic Retrofit of Masonry Bridges Using Micropiles, Master's Thesis, Department of Civil, Architectural and Environmental Engineering, Graduate College of the Illinois Institute of Technology, Chicago.

[8] Cancelliere, I., İmbimbo, M., Sacco. E.: Experimental tests and numerical modeling of reinforced masonry arches, Engineering Structures, 32 (2010), pp. 776-792, doi: http://dx.doi.org/10.1016/j. engstruct.2009.12.005

[9] Arıoğlu, N., Acun, S.: The Evaluation of Lime Mortars and Plasters with The Purpose of Conservation and Restoration, New Perspectives To Save The Cultural Heritage, CIPA 2003 International Symposium, Antalya-Türkiye, (2003), pp. 571-576.

[10] BASF Chemical Company, Albaria Calce Albazzana Technical Sheet, http://imeryapi.com.tr/wp-content/uploads/ALBARIACALCE-ALBAZZANA.pdf

[11] TS 699: 2009. Methods of Testing for Natural Building Stones, Turkish Building Code, Turkish Standards Institution, Ankara, Turkey
[12] TS EN 1467:2012. Natural stone - Rough blocks - Specifications, Turkish Building Code, Turkish Standards Institution, Ankara, Turkey.

[13] TS EN 1469. Natural stone products - Slabs for cladding Requirements, Turkish Building Code, Turkish Standards Institution, Ankara, Turkey.

[14] Turker, T.: Determination of dynamic characteristics of steel frames by experimental modal analysis method, Master's Thesis, Graduate School of Natural And Applied Sciences, 2005., Karadeniz Teknik University, Trabzon, Turkey.

[15] Cakir, F., Uysal, H.: Experimental modal analysis of brick masonry arches strengthened prepreg composites, Journal of Cultural Heritage, (2014), doi: http://dx.doi.org/10.1016/j. culher.2014.06.003.

[16] Product Data, Impact Hammers - Types 8206, 8206-001, 8206002 and 8206-003, Brüel\&Kjaer, Denmark

[17] Kaya, Y.: Tools and Techniques for Real Time Modal Identification, Ph.D. Thesis, Graduate Program in Earthquake Engineering, Bogazici University, Istanbul, Turkey, 2009

[18] TEC: Turkish Earthquake Code, Specification for Structures to Be Built in Disaster Areas, Ministry of Environment and Urbanization of Turkey, 2007.

[19] Lourenço, P., Vasconcelos, G., Ramos, L.: Assessment of the Stability Conditions of a Cistercian Cloister, Second International Congress of Studies in Ancient Structures, (2001), Istanbul.

[20] Bayraktar, A., Altunisik, A., Sevim, B., Türker, T.: Finite Element Model Updating of Kömürhan Highway Bridge, IMO Teknik Dergi, (2009), pp. 4675- 4700.

[21] Sahin, A.: Digital Signal Processing, Dynamic Characteristic Identification and Finite Element Model Updating Software for Experimental and Operational Modal Testing of Structures: SignalCAD - ModalCAD - FemUP (PhD Thesis), Graduate School of Natural And Applied Sciences, Karadeniz Teknik University, Trabzon, 2009

[22] Ewins, D.: Modal Testing, Theory, Practice, and Application (Mechanical Engineering Research Studies: Engineering Dynamics Series), Research Studies Press LTD., England, 2010. 